\title{
A new significant and independent risk factor for falls in elderly men and women: a low creatinine clearance of less than $65 \mathrm{ml} / \mathrm{min}$
}

\author{
Laurent C. Dukas · Erich Schacht · Ze'ev Mazor \\ Hannes B. Stähelin
}

Received: 31 March 2004/ Accepted: 7 June 2004/ Published online: 8 July 2004

(C) International Osteoporosis Foundation and National Osteoporosis Foundation 2004

\begin{abstract}
Objectives: Because impaired renal function is detrimental for the conversion of calcidiol to calcitriol (D-hormone) and since D-hormone analogues have been shown to decrease the risk of falls, we investigated whether creatinine clearance $(\mathrm{CrCl})$ is associated with the number of fallers and falls in elderly men and women. Methods: Within a randomized controlled study, we observed for 36 weeks 186 placebo-treated community-dwelling elderly men and women over 70 , in an attempt to determine the influence of baseline $\mathrm{CrCl}$ on calcitropic hormone serum levels, as well as the influence of baseline $\mathrm{CrCl}$ on the number of fallers and falls over time. With the help of questionnaires, we regularly assessed fall incidence and frequency. The risk of falls and the risk of becoming a faller were assessed in multivariate-controlled logistic regression models according to a cutoff value of the $\mathrm{CrCl}$ set at $65 \mathrm{ml} / \mathrm{min}$. Results: At baseline, serum levels of $1.25(\mathrm{OH})_{2} \mathrm{D}_{3}$ and $\mathrm{iPTH}$ were, in multivariate-controlled analyses, significantly associated
\end{abstract}

The study was supported by the following institutions: TEVA Pharmaceuticals Industries, Israel, and University Hospital Basel, Switzerland (scientific grant).

L.C. Dukas $(\bowtie)$

Geriatric University Clinic, Kantonsspital, Ambulatorium

Wiesendamm, Wiesendamm 22, 4057 Basel, Switzerland

E-mail: 1.d@gmx.net

Tel.: + 41-61-6312525

Fax: + 41-61-6314038

H.B. Stähelin

Geriatric University Clinic, Kantonsspital, 4031 Basel, Switzerland

E-mail: hannes-b.staehelin@unibas.ch

Tel: + 41-61-2652954

Fax: $+41-61-2652670$

E. Schacht

Metabolic Bone Disease Unit, Universitätsklinik Balgrist, Zurich, Switzerland

Z. Mazor

Bone Metabolism Unit, TEVA Pharmaceutical Industries,

Jerusalem, Israel with $\mathrm{CrCl}(p<0.0001, p=0.001$, respectively), whereas serum levels of $25(\mathrm{OH}) \mathrm{D}_{3}$ were not associated with $\mathrm{CrCl}$. Below a $\mathrm{CrCl}$ of $65 \mathrm{ml} / \mathrm{min}, 1.25(\mathrm{OH})_{2} \mathrm{D}_{3}$ serum levels steadily declined. We therefore chose a $\mathrm{CrCl}$ of $65 \mathrm{ml} / \mathrm{min}$ as cutoff for further analyses. During the 36 weeks of observation, elderly people with a $\mathrm{CrCl}$ of $<65 \mathrm{ml} / \mathrm{min}$ had, in multivariate controlled analyses, compared with elderly with a $\mathrm{CrCl}$ of $\geq 65 \mathrm{ml} / \mathrm{min}$, a significantly higher incidence of number of fallers $(25 / 70$ vs $21 / 116 ; \mathrm{OR}=4.01 ; 95 \% \mathrm{CI}, 1.48-10.98 ; p=0.006$ ), and a significantly higher incidence of falls $(28 / 70$ vs $23 /$ 116 ; OR $=3.68 ; 95 \%$ CI, $1.38-9.82 ; p=0.009$ ). Conclusions: For the first time we showed that in a communitydwelling population of elderly men and women, a $\mathrm{CrCl}$ of less than $65 \mathrm{ml} / \mathrm{min}$ is a significant and independent risk factor for fallers and falls.

Keywords Creatinine clearance - Elderly - Fallers · Falls $\cdot$ D-Hormone

\section{Introduction}

The risk of falling increases with aging. In elderly men and women, falls are, independent of the increased incidence of fall-related fractures [1, 2], associated with loss of independence [3], deterioration of quality life, and increased mortality [4]. Several studies have investigated the risk factors for falls in the elderly $[5,6,7]$. Among others, vitamin D deficiency and/or low D-hormone (calcitriol/1,25(OH $)_{2} \mathrm{D}_{3}$ ), associated with a decrease of muscle strength $[8,9,10,11]$, decreased balance $[8,12,13]$, and loss of functional mobility [13, 14], are more and more recognized to be important risk factors for falls in the elderly. Several recently published studies have shown that supplementation of vitamin D in vitamin D-deficient institutionalized women [15] and treatment with either calcitriol in osteopenic vitamin D-replete women [16] or alfacalcidol, a D-hormone 
prodrug, in a population of community-dwelling elderly non-vitamin D-deficient men and women [17] can significantly reduce frequency of falls $[15,16,17]$ and number of fallers [17].

The conversion of calcidiol $\left(25(\mathrm{OH}) \mathrm{D}_{3}\right)$ to the metabolically most active form of vitamin $\mathrm{D}$, the D-hormone (calcitriol/1.25(OH) ${ }_{2} \mathrm{D}_{3}$ ), is highly dependent on the creatinine clearance $[18,19]$. It is hypothesized that below a creatinine clearance of $60 \mathrm{ml} / \mathrm{min} \mathrm{[20]} \mathrm{or} 50 \mathrm{ml} /$ $\min$ [21], the renal conversion of $25(\mathrm{OH}) \mathrm{D}_{3}$ to $1.25(\mathrm{OH})_{2} \mathrm{D}_{3}$ becomes insufficient [20, 21]. Several studies $[8,9,22]$ suggest that even a slight decrease in $1.25(\mathrm{OH})_{2} \mathrm{D}_{3}$ and a corresponding slight increase in iPTH serum levels, observed when creatinine clearance $(\mathrm{CrCl})$ decreases to $60-80 \mathrm{ml} / \mathrm{min}$ [23], is associated with subclinical myopathy and balance trouble. It is nowadays accepted that the related increased occurrence of falling, together with increased skeletal fragility, has a larger effect on age-related increased frequency of fractures than bone mass alone $[22,24]$. According to the currently published updated K/DOQL (Kidney disease outcomes quality initiative guidelines by the US Kidney Foundation) [25], a slight decrease of the $\mathrm{CrCl}$ is associated with a decrease in bone mineral density [26], and since a $\mathrm{CrCl}$ below $60 \mathrm{ml} / \mathrm{min}$ increases significantly the risk of fractures, the guidelines suggest an intensive control of patients with decreased creatinine clearance $[25,26]$.

Aging is associated with a deterioration of renal function, easily measurable as deterioration of the creatinine clearance, and several studies suggest that a significant number of elderly people, even with normal vitamin D serum levels ( $>12 \mathrm{ng} / \mathrm{ml}$ ), may suffer from a deficiency of $1.25(\mathrm{OH})_{2} \mathrm{D}_{3}[27,28,29]$, due to the age-related impaired renal function and the consecutively decreased activity of the renal $1 \alpha$-hydroxylase [21, 30].

Since aging is associated with a decreasing creatinine clearance and consequently with decreased serum levels of $1.25(\mathrm{OH})_{2} \mathrm{D}_{3}$ and since low $1.25(\mathrm{OH})_{2} \mathrm{D}_{3}$ serum levels have been associated with risk of falls, we investigated whether creatinine clearance is a risk factor for falls.

\section{Subjects and methods}

\section{Participants}

This investigation was conducted as post hoc subanalysis in the framework of the Swiss Aims Study [17]. The Aims study was a large double-blind placebo-controlled randomized study to assess the influence of alfacalcidol (1-alpha-dihydroxy-cholecalcitriol, Bondiol; GRY Pharma, Germany), a $1.25(\mathrm{OH})_{2} \mathrm{D}_{3}$ prodrug, on frequency of fallers and falls in community-dwelling elderly men and women, 70 years old and older. The follow-up was 36 weeks. The subjects of this investigation were the
186 participants randomized to placebo, comprising 90 men and 96 women [17]. All subjects underwent a medical examination and biochemical tests, and answered a food frequency questionnaire. Falls were assessed every 12 weeks after the baseline visit for a total of 36 weeks. Details of assessment of falls were described previously [17]. The protocol of this study was approved by the Ethical Review Board of the University of Basel and all participants provided written informed consent. The Data, Safety and Monitoring Board established by GWD Consult Germany (Safety and Monitoring Board, GWD Consult, Research Contract, Postfach 1210, 63152, Mülheim/Main, Germany) reviewed the conduct of the study.

\section{Methods}

The dietary calcium and vitamin D intake was estimated by using a food frequency questionnaire, which also produced information on some demographic, lifestyle, and nutritional parameters [17]. Calcium was not supplied, none of the participants were receiving physical therapy or training programs at study entry, and no attempt was made to alter subjects' diets or physical activity during the study. Each subject was asked to keep a diary on fall incidence and to inform the study center by a telephone call within $48 \mathrm{~h}$. At each study-site visit, data on fall incidence were reassessed (date, time, circumstances, injuries) by trained study nurses using an interview-administered, not validated, questionnaire. Falls were defined as "unintentionally coming to rest on the ground, floor, or other lower level." With the permission of the participants all case reports of fall incidences were collected from the house physician or hospitals. In all subjects, blood samples were drawn for measurement of serum calcium, phosphate, creatinine, $25(\mathrm{OH}) \mathrm{D}_{3}, 1.25(\mathrm{OH})_{2} \mathrm{D}_{3}$, and $\mathrm{iPTH}$. Serum levels of $25(\mathrm{OH}) \mathrm{D}_{3}, 1.25(\mathrm{OH})_{2} \mathrm{D}_{3}$, and $\mathrm{iPTH}$ were measured by radioimmunoassay (Nichols): intra-assay variation was $5.1 \%, 5.0 \%$, and 1.8 ; interassay variation was $7.9 \%$, $10.8 \%$, and $5.6 \%$. All samples were immediately frozen at $-80^{\circ} \mathrm{C}$ and analyzed by the same person in one batch. Normal ranges for adults were for iPTH $<65 \mathrm{pg} / \mathrm{ml}$, for $25(\mathrm{OH}) \mathrm{D}_{3} \quad 12-124 \mathrm{ng} / \mathrm{ml}$, and for $1.25(\mathrm{OH})_{2} \mathrm{D}_{3} 30$ $76 \mathrm{pmol} / 1$. Creatinine clearance was calculated with the widely accepted formula from Cockroft et al., adjusted for gender [31].

The statistical analyses were conducted using the SAS statistical software package, version 8.2 , by the SAS Institute, Cary, NC, USA, licensed to the University of Basel, Switzerland. Comparisons of means were performed by multivariate-adjusted analyses of variance [32]. Since $\mathrm{iPTH}, 25(\mathrm{OH}) \mathrm{D}_{3}$, and $1.25(\mathrm{OH})_{2} \mathrm{D}_{3}$ distributions were markedly skewed, logarithmic transformations of these variances were performed prior to analyses. The relationship between $1.25(\mathrm{OH})_{2} \mathrm{D}_{3}$ and creatinine clearance was studied by multivariate-adjusted linear regression analyses. The determination of 
Table 1 Characteristics of the study participants $(N=186)$. BMI body mass index, $i P T H$ intact parathormone

\begin{tabular}{lc}
\hline & Characteristics \\
\hline Gender, number of males/females & $90 / 96$ \\
Age, years (mean $\pm \mathrm{SD})$ & $75.0 \pm 4.1$ \\
$\mathrm{BMI}, \mathrm{kg} / \mathrm{m}^{2}(\mathrm{mean} \pm \mathrm{SD})$ & $26.7 \pm 4.1$ \\
$\mathrm{Laboratory}(\mathrm{mean} \pm \mathrm{SD})$ & \\
$\mathrm{iPTH}, \mathrm{pg} / \mathrm{ml}$ & $39.1 \pm 24.5$ \\
$1.25(\mathrm{OH})_{2} \mathrm{D}_{3}, \mathrm{pg} / \mathrm{ml}$ & $39.1 \pm 10.9$ \\
$25(\mathrm{OH}) \mathrm{D}_{3}, \mathrm{ng} / \mathrm{ml}$ & $28.3 \pm 10.7$ \\
Albumin, $\mathrm{g} / \mathrm{l}$ & $42.3 \pm 3.1$ \\
Creatinine clearance, $\mathrm{ml} / \mathrm{min}$ & $78.0 \pm 20.3$ \\
\hline
\end{tabular}

the appropriate cutoff point for the $\mathrm{CrCl}$ to be used for further analyses was determined using a receiver operating characteristic (ROC) curve [33]. Five percent significance level was maintained throughout these analyses, and all tests were two-sided.

\section{Results}

\section{General}

The mean age of the slightly overweight (mean BMI $26.7 \pm 4.1 \mathrm{~kg} / \mathrm{m}^{2}$ ) participants was 75 years $(75.0 \pm 4.1)$ (Table 1). Mean laboratory values for $\mathrm{iPTH}, 25(\mathrm{OH}) \mathrm{D}_{3}, 1.25(\mathrm{OH})_{2} \mathrm{D}_{3}$, and albumin serum levels were within the normal range, the mean creatinine clearance was slightly reduced $(78.0 \pm 20.3 \mathrm{ml} / \mathrm{min})$ (Table 1).

Fig. 1 Association between $25(\mathrm{OH}) \mathrm{D}_{3}$ (calcidiol) serum levels and creatinine clearance
Associations between creatinine clearance and calcitropic hormones, calcium and phosphate serum levels

Serum levels of $25(\mathrm{OH}) \mathrm{D}_{3}$ were not associated with creatinine clearance $(p=0.62)$ (Fig. 1). Serum levels of $1.25(\mathrm{OH})_{2} \mathrm{D}_{3}$ were significantly associated with creatinine clearance $(p<0.001)$ (Fig. 2). In the ROC analysis of the association between $1.25(\mathrm{OH})_{2} \mathrm{D}_{3}$ and the creatinine clearance, the cutoff value for the creatinine clearance came out to be at $65 \mathrm{ml} / \mathrm{min}$. Below a creatinine clearance of $65 \mathrm{ml} / \mathrm{min}, 1.25(\mathrm{OH})_{2} \mathrm{D}_{3}$ serum levels steadily declined (Fig. 2), and participants with a creatinine clearance of less than $65 \mathrm{ml} / \mathrm{min}$ had significantly lower mean $1.25(\mathrm{OH})_{2} \mathrm{D}_{3}$ serum levels than participants with a creatinine clearance above $65 \mathrm{ml} /$ $\min (p=0.001)$ (Table 2). We therefore chose a creatinine clearance of $65 \mathrm{ml} / \mathrm{min}$ as a cutoff level for our further analyses and participants were accordingly classified in two groups (creatinine clearance $<65 \mathrm{ml}$ / $\min$ vs $\geq 65 \mathrm{ml} / \mathrm{min}$ ). In the group with a creatinine clearance of $<65 \mathrm{ml} / \mathrm{min}, 7 \%$ had a creatinine clearance of $<40 \mathrm{ml} / \mathrm{min}$. For the other controlled variables, we found no significant differences between groups (Table 2).

Association between creatinine clearance and number of fallers and number of falls

The multivariate analyses included predictors which have been previously shown to be associated with increased risk of falling or variables which were significantly different between participants with a creatinine clearance $\geq 65 \mathrm{ml} / \mathrm{min}$ and those with a creatinine clearance of $<65 \mathrm{ml} / \mathrm{min}$. These variables were

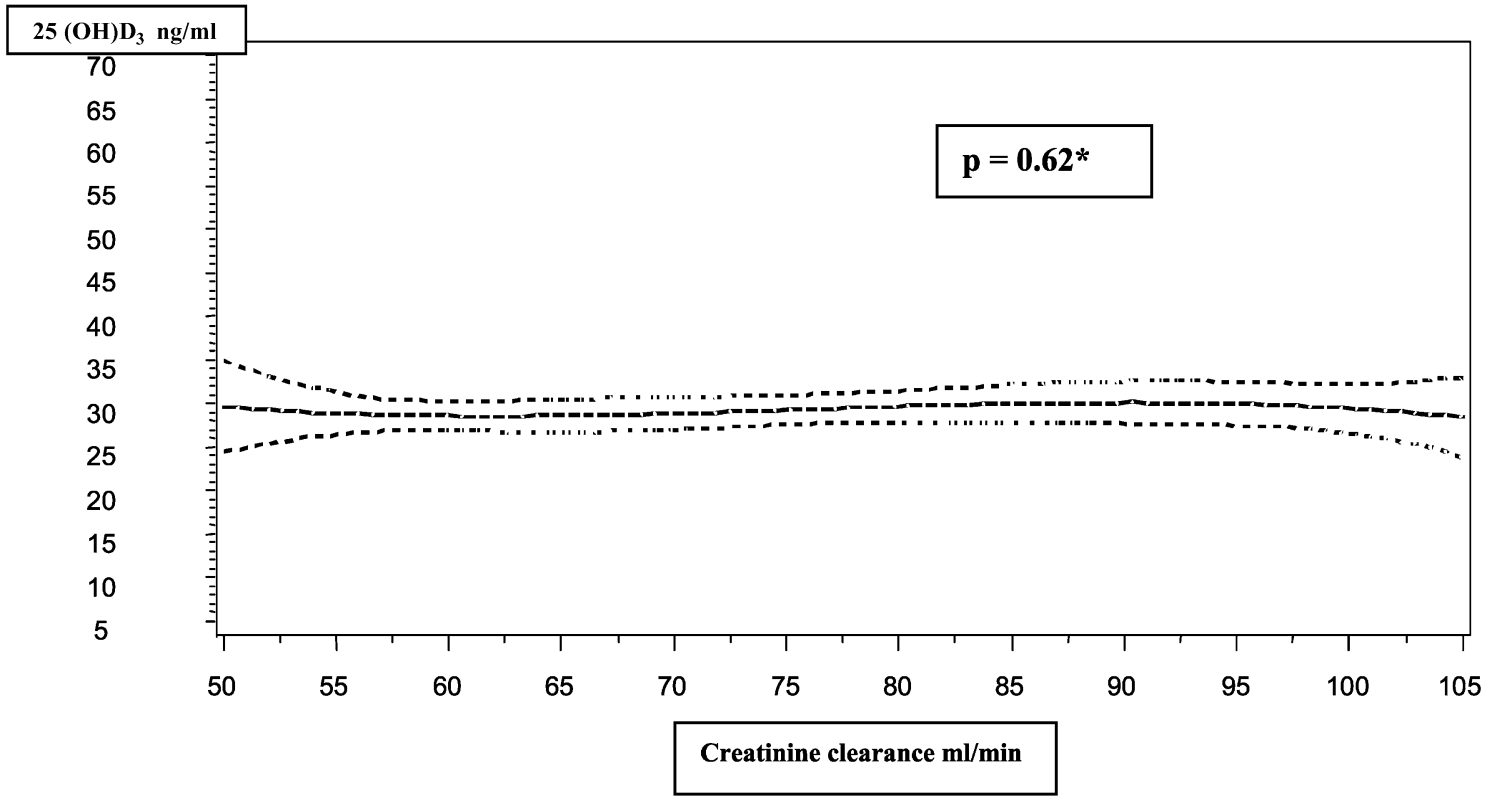

* controlled for gender, age, BMI, number of comorbidities and use of diuretics 


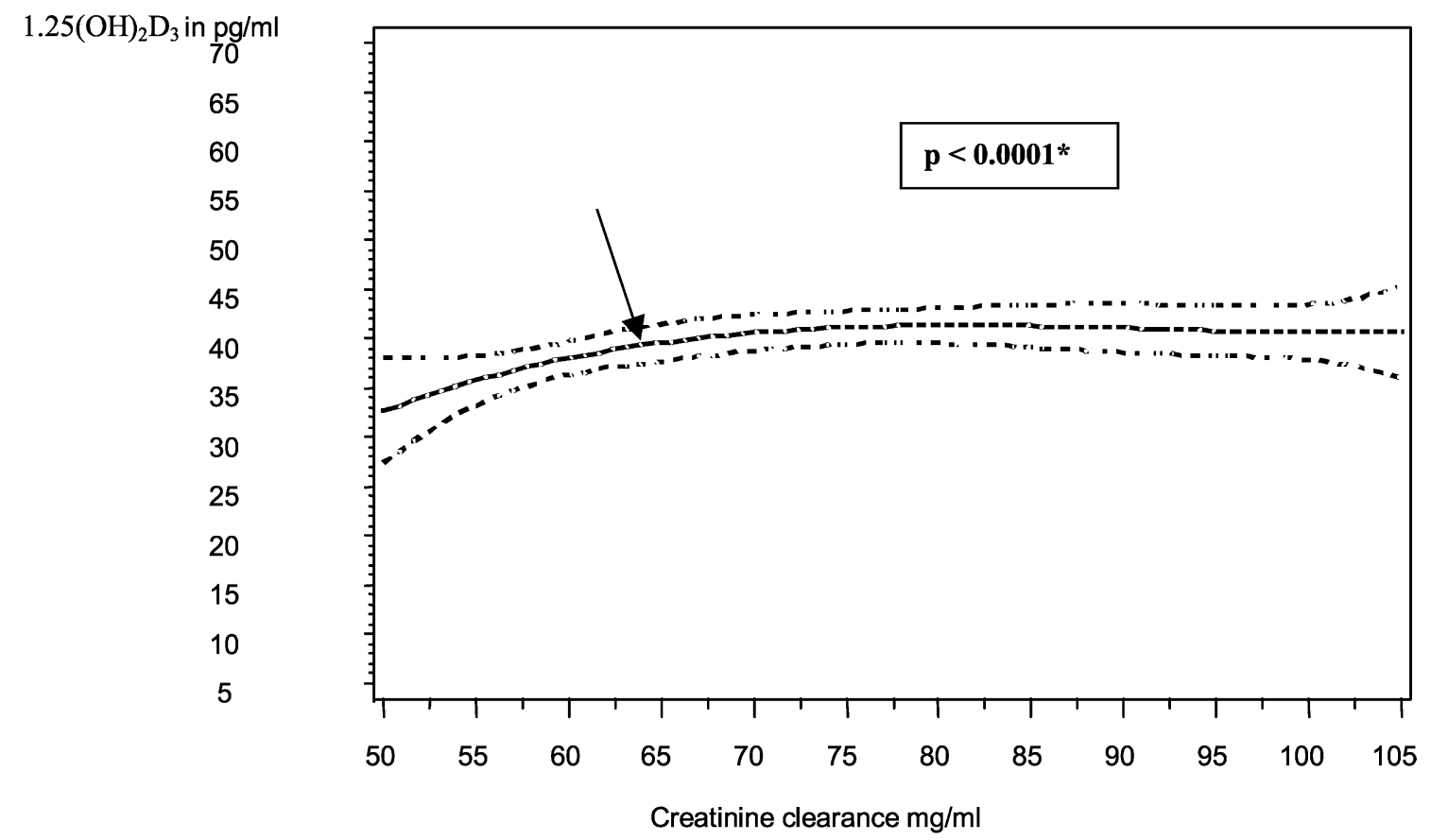

* controlled for age, gender, BMI, number of comorbidities, use of diuretics and Calcidiol serum levels

Fig. 2 Association between $1.25(\mathrm{OH})_{2} \mathrm{D}_{3}$ (D-hormone) serum levels and creatinine clearance

age, gender, body mass index (BMI), number of falls in previous 3 months, physical activity (sport yes/no), heart rate at baseline ( $<80$ beats/min vs $\geq 80$ beats/min), Charlson comorbidity index, dietary calcium intake, iPTH $(\mathrm{pg} / \mathrm{ml}), 25(\mathrm{OH}) \mathrm{D}_{3}(\mathrm{ng} / \mathrm{ml}), 1,25(\mathrm{OH})_{2} \mathrm{D}_{3}(\mathrm{pg} /$ $\mathrm{ml})$, and albumin $(\mathrm{g} / \mathrm{l})$ serum levels at baseline, changes of iPTH $(\mathrm{pg} / \mathrm{ml}), 25(\mathrm{OH}) \mathrm{D}_{3}(\mathrm{ng} / \mathrm{ml})$, and $1,25(\mathrm{OH})_{2} \mathrm{D}_{3}$ $(\mathrm{pg} / \mathrm{ml})$ serum levels over time, total number of medications $(\mathrm{N})$, use of phenprocoumon, estrogen, and diuretics, coffee intake, and intake of multivitamins. Number of comorbidities was assessed with the Charlson comorbidity index and was also included as a control variable in the analyses.

During the 36 weeks of observation, the elderly community-dwelling men and women with a creatinine clearance of $<65 \mathrm{ml} / \mathrm{min}$ had, in multivariate-controlled analyses, compared with the participants with a creatinine clearance of $\geq 65 \mathrm{ml} / \mathrm{min}$, a significantly higher incidence of number of fallers ( 25 out of 70 vs 21 out of $116 ; \mathrm{OR}=4.01 ; 95 \% \mathrm{CI}, 1.48-10.89 ; p=0.006)$ and a significantly higher incidence of falls ( 28 falls in 70 elderly vs 23 falls in 116 elderly; $\mathrm{OR}=3.68$; $95 \% \mathrm{CI}, 1.38$ 9.82; $p=0.009$ ) (Table 3).

\section{Discussion}

We observed a significant relationship between creatinine clearance $(\mathrm{CrCl})$ and $1.25(\mathrm{OH})_{2} \mathrm{D}_{3}$ serum levels. We found no association between $\mathrm{CrCl}$ and $25(\mathrm{OH}) \mathrm{D}_{3}$ serum levels. In our population, a creatinine clearance of less than $65 \mathrm{ml} / \mathrm{min}$ (low creatinine clearance) was associated with declining $1.25(\mathrm{OH})_{2} \mathrm{D}_{3}$ serum levels. A creatinine clearance of less than $65 \mathrm{ml} / \mathrm{min}$ is considered a modest impairment of kidney function. Whereas, participants with a low creatinine clearance had significantly lower mean $1.25(\mathrm{OH})_{2} \mathrm{D}_{3}$ serum levels than participants with a creatinine clearance of $\geq 65 \mathrm{ml} / \mathrm{min}$, mean serum levels of $25(\mathrm{OH}) \mathrm{D}_{3}$ and $\mathrm{iPTH}$ were not significantly different between groups. Other authors found similar relationships between $1.25(\mathrm{OH})_{2} \mathrm{D}_{3}$ and creatinine clearance [20,21]. Francis et al. observed in women with normal calcidiol serum levels, low $1.25(\mathrm{OH})_{2} \mathrm{D}_{3}$ serum levels (defined as $<31 \mathrm{pg} / \mathrm{ml}$ ) with a creatinine clearance below $50 \mathrm{ml} / \mathrm{min}$ [21].

Deficiency values for vitamin $\mathrm{D}$, and accordingly low values for $1.25(\mathrm{OH})_{2} \mathrm{D}_{3}$ (D-hormone/calcitriol), were established based on the concept of the classic deficiency diseases. However, functional parameters that have been related to vitamin $\mathrm{D}$ and $1.25(\mathrm{OH})_{2} \mathrm{D}_{3}$ decline at serum levels which are above the defined deficiency levels. Serum concentrations of $1.25(\mathrm{OH})_{2} \mathrm{D}_{3}$, which are significantly above the lowest defined normal value of $1.25(\mathrm{OH})_{2} \mathrm{D}_{3}$, respectively associated increases in iPTH serum levels, have been shown to have a negative impact on muscle strength and functional mobility $[8,9]$ and have been related to myopathy $[9,10,11,28,34]$. Serum levels of $1.25(\mathrm{OH})_{2} \mathrm{D}_{3}$ have been associated with decreased muscle strength, lower endurance $[8,9,10,11$, 12], reduced functional mobility [13, 14], and atrophy of fast-twitch muscle fibers [35]. Also, $1.25(\mathrm{OH})_{2} \mathrm{D}_{3}$ is an effective treatment of the iPTH-related decrease of energy metabolism in skeletal muscle and proteolysis of muscle proteins $[36,37,38]$. Low $1.25(\mathrm{OH})_{2} \mathrm{D}_{3}$ serum 
Table 2 Characteristics of the study participants at baseline according to creatinine clearance $(\mathrm{CrCl})$. BMI body mass index, $i P T H$ intact parathormone, QUS quantitative ultrasound (calcaneus)

\begin{tabular}{|c|c|c|c|}
\hline & $\begin{array}{l}\mathrm{CrCl}<65 \mathrm{ml} / \mathrm{min} \\
(N=70)\end{array}$ & $\begin{array}{l}\mathrm{CrCl} \geq 65 \mathrm{ml} / \mathrm{min} \\
(N=116)\end{array}$ & $p$ Value \\
\hline Gender, number of males/females & $28 / 42$ & $62 / 54$ & 0.075 \\
\hline Age, years (mean \pm SD) & $76.6 \pm 4.6$ & $74.0 \pm 3.4$ & $<.0001$ \\
\hline $\mathrm{BMI}, \mathrm{kg} / \mathrm{m}^{2}($ mean $\pm \mathrm{SD})$ & $24.7 \pm 3.0$ & $28.0 \pm 4.2$ & $<.0001$ \\
\hline \multicolumn{4}{|l|}{ Laboratory (mean $\pm \mathrm{SD})$} \\
\hline iPTH, pg/ml & $40.9 \pm 32.5$ & $38.0 \pm 18.0$ & 0.331 \\
\hline $1.25(\mathrm{OH})_{2} \mathrm{D}_{3}, \mathrm{pg} / \mathrm{ml}$ & $37.9 \pm 12.4$ & $40.6 \pm 9.7$ & 0.001 \\
\hline $25(\mathrm{OH}) \mathrm{D}_{3}, \mathrm{ng} / \mathrm{ml}$ & $27.2 \pm 10.9$ & $29.0 \pm 10.5$ & 0.184 \\
\hline Albumin, $\mathrm{g} / \mathrm{l}$ & $42.1 \pm 3.0$ & $42.7 \pm 3.2$ & 0.167 \\
\hline Calcium, mmol/1 & $2.31 \pm 0.09$ & $2.30 \pm 0.11$ & 0.502 \\
\hline Phosphate, mmol/1 & $1.02 \pm 0.20$ & $0.98 \pm 0.18$ & 0.178 \\
\hline \multicolumn{4}{|l|}{ Drug intake } \\
\hline Multivitamin use prior to the study & $11.4 \%$ & $3.5 \%$ & 0.032 \\
\hline Estrogen use & $10.0 \%$ & $11.2 \%$ & 0.797 \\
\hline Use of diuretics & $17.1 \%$ & $13.8 \%$ & 0.536 \\
\hline \multicolumn{4}{|l|}{ Other variables (in $\%$ or mean $\pm \mathrm{SD}$ ) } \\
\hline $\begin{array}{l}\text { Participants experiencing a fall in } \\
\text { the } 3 \text { months prior to study entry }\end{array}$ & $22.9 \%$ & $16.4 \%$ & 0.536 \\
\hline Regular physical activity & $31.4 \%$ & $45.7 \%$ & 0.055 \\
\hline Daily dietary calcium intake, $\mathrm{mg}$ & $512 \pm 196$ & $530 \pm 167$ & 0.353 \\
\hline Bone Quality QUS, $T$-score & $-0.84 \pm 1.79$ & $-0.54 \pm 1.34$ & 0.256 \\
\hline Timed up \& go test, seconds & $7.1 \pm 1.9$ & $6.9 \pm 1.5$ & 0.918 \\
\hline
\end{tabular}

Table 3 Multivariate OR for number of fallers and falls in elderly men and women during 36 weeks of observation, according to a creatinine clearance of $<65 \mathrm{ml} / \mathrm{min}$ vs $\geq 65 \mathrm{ml} / \mathrm{min}$. $O R$ odds ratio, $95 \%$ CI $95 \%$ confidence interval

\begin{tabular}{llc}
\hline & $\begin{array}{l}\text { Multivariate } \\
\text { adjusted } \\
\text { OR }(95 \% \mathrm{CI})\end{array}$ & $p$ Value \\
\hline Fallers & $4.01(1.48-10.98)$ & 0.006 \\
Falls & $3.68(1.38-9.82)$ & 0.009
\end{tabular}

${ }^{\mathrm{a}}$ Adjusted for age, gender, BMI, physical activity, iPTH, calcidiol, D-hormone, and albumin serum levels at baseline; changes of iPTH, $25(\mathrm{OH}) \mathrm{D}_{3}$, and $1.25(\mathrm{OH})_{2} \mathrm{D}_{3}$ serum levels over observation time; use of phenprocoumon, estrogens, diuretics, and multivitamins; number of comorbidities, total number of medications, coffee intake, physical activity, and previous falls

levels and related high normal iPTH levels have been associated with subclinical myopathy $[10,11,39]$. In one study, $1.25(\mathrm{OH})_{2} \mathrm{D}_{3}$ has been shown to reduce the release of interleukin 6 (IL-6) from human blood monocytes, while $25(\mathrm{OH}) \mathrm{D}_{3}$ was ineffective [40]. In another study, $1.25(\mathrm{OH})_{2} \mathrm{D}_{3}$ increased insulin-like growth factor (IGF-I) in vivo [41]. Both factors - increasing IL-6 and decreasing IGF-I - are synergistic risk factors for functional disability [42]. The results from these studies $[9,10,11,28,29,30,40,41,42]$ suggest that $1.25(\mathrm{OH})_{2} \mathrm{D}_{3}$ is an independent risk factor for decreased muscle strength [12, 13], reduced functional mobility [14], and for falls [8, 16, 17, 43], suggesting a direct involvement of $1.25(\mathrm{OH})_{2} \mathrm{D}_{3}$ in the causal pathogenic pathway of decreased muscle strength-related falls [39].

Specific receptors for $1.25(\mathrm{OH})_{2} \mathrm{D}_{3}$ have been found in muscle tissue $[44,45]$. Sorenson et al. showed that fast-twitch type II muscle fibers atrophy in the absence of $1.25(\mathrm{OH})_{2} \mathrm{D}_{3}$ and reappear by treatment with alfacalcidol [35]. Analogues of $1.25(\mathrm{OH})_{2} \mathrm{D}_{3}$ (D-hormone) have been shown to have an effect on muscle power and neuromuscular coordination $[39,43,46,47,48]$. The results of these studies, as well as our finding that the only significant difference in participants with a low creatinine clearance compared with participants with a creatinine clearance of $\geq 65 \mathrm{ml} / \mathrm{min}$ was the difference in mean $1.25(\mathrm{OH})_{2} \mathrm{D}_{3}$ serum levels, suggest that the main vitamin $\mathrm{D}$-dependent effect on muscle and locomotion comes from the most active form of vitamin $\mathrm{D}$, the $1.25(\mathrm{OH})_{2} \mathrm{D}_{3}$ (D-hormone). We therefore conclude that our observed approximately four times increased risk of falls observed in participants with a low creatinine clearance is due to a creatinine clearance-dependent decrease in $1.25(\mathrm{OH})_{2} \mathrm{D}_{3}$ serum levels. A creatinine clearance below $65 \mathrm{ml} / \mathrm{min}$ can be considered as a surrogate parameter for low $1.25(\mathrm{OH})_{2} \mathrm{D}_{3}$ serum levels. Treatment options for patients should therefore clearly differentiate between the nutritive vitamin $\mathrm{D}$ deficiency and the metabolic low D-hormone syndrome.

Several risk assessment tools are proposed for the detection of elderly with an increased risk for falls and for preventive intervention. These tools are mostly used in fall assessment clinics because they are time consuming and need a trained risk assessment team. These risk assessment tools help to identify several risk factors for falls and offer the possibility of multifactorial intervention. While several studies have shown that multifactorial intervention may prevent falls, other studies have shown that multifactorial interventions are not appropriate for all elderly and that they fail in preventing falls $[49,50]$. In general, the determination of the creatinine clearance is of great clinical utility in the identification of elderly with an increased risk for falls since its determination offers multiple advantages. Compared with the determination of $1.25(\mathrm{OH})_{2} \mathrm{D}_{3}$, the measurement of serum creatinine to calculate creatinine 
clearance is easy, cheap, and independent of seasonal or diurnal variations.

In our study, elderly men and women with a creatinine clearance below $65 \mathrm{ml} / \mathrm{min}$ had, in multivariatecontrolled analyses, a fourfold increased risk to become fallers and a 3.7-fold increased risk for falls, during an observation time of 36 weeks. In a retrospective analysis of an observational, not-yet-published study in Germany on incidence of osteoporosis, falls, and creatinine clearance among 5,441 German osteoporotic women and men aged 60-92 years, based on our cutoff value of $65 \mathrm{ml} / \mathrm{min}$, a low creatinine clearance was compared with a creatinine clearance of $\geq 65 \mathrm{ml} / \mathrm{min}$ also associated with an increased risk for falls and fractures (E. Schacht, Metabolic Bone Disease Unit. Universitätsklinik Balgrist, Zurich, Switzerland, personal communication). We are the first to show that a low creatinine clearance is associated with an increased risk of falls.

Our results have several limitations. The results come from post hoc analyses. The participants were Caucasian community-dwelling men and women over the age of 70 , so our findings are not generalizable to a younger population, to the institutionalized elderly, or to men and women of other races. Since our analyses were done with participants who received placebo during 36 weeks, we can not rule out an influence in either direction of placebo on risk of falls. Assessment of risk factors for falls, as well as the large part of the incidence of falls, during the study was based only on the participant's own report. Finally we can not exclude uncontrolled confounding.

In conclusion, a low creatinine clearance of $<65 \mathrm{ml} /$ $\mathrm{min}$, as a surrogate parameter for low creatinine clearance-associated low $1.25(\mathrm{OH})_{2} \mathrm{D}_{3}$ serum levels, is a significant, independent, and easily measurable risk factor for falls, associated with a fourfold increased risk to become a faller and a 3.7-fold increased risk to experience a fall.

Acknowledgements We are indebted to the participants and all our study coworkers; to the team of the laboratory of Rheumatology at the Felix-Platter Spital, Basel, Switzerland; as well as to the team of the Hospital Pharmacy of the Kantonsspital, Basel, Switzerland; to Professor John Orav (Division of Clinical Epidemiology, Brigham and Women's Hospital, Boston, MA, USA) for statistical consultation and advice; to Dr A. Monsch for advice and encouragement in the preparation of the study protocol and study conduct.

\section{References}

1. Youm T, Koval KJ, Kummer FJ et al (1999) Do all hip fractures result from a fall? Am J Orthop 28:190-119

2. Lips P (1997) Epidemiology and predictors of fractures associated with osteoporosis. Am J Med 103(2A):3S-8S

3. Tinetti ME, Williams CS (1997) Falls, injuries due to falls, and the risk of admission to a nursing home. $\mathrm{N}$ Engl $\mathrm{J}$ Med 337:1279-1284

4. Tinetti ME, Williams CS (1998) The effect of falls and fall injuries on functioning in community-dwelling older persons. J Gerontol A Biol Sci Med Sci 53:M112-M119
5. Tinetti ME (2003) Preventing falls in elderly persons. N Engl J Med 348(1):42-49

6. Nevitt MC, Cummings SR, Hudes ES (1989) Risk factors for recurrent nonsyncopal falls: a prospective study. JAMA 261:2663-2668

7. Sattin RW (1992) Falls among older persons: a public health perspective. Annu Rev Public Health 13:489-508

8. Chapuy MC, Preziosi P, Maamer M, Arnaud S, Galan P, Hersberg S, Meunier PJ (1997) Prevalence of vitamin D insufficiency in an adult normal population. Osteoporos Int 7:439-443

9. Peacock M, Selby PL, Francis RM, Brown WB, Hordon L (1985) Vitamin D deficiency, insufficiency, sufficiency and intoxication. What do they mean? In: Norman A et al (eds) Sixth workshop on vitamin D. de Gruyter, Berlin, pp 569570

10. Peacock M, Heyburn P (1977) Effect of vitamin $D_{3}$ metabolites on proximal muscle weakness. Calcif Tiss Res 24[Suppl]:R20 R23

11. Schott GD, Wills MR (1976) Muscle weakness in osteomalacia. Lancet 20:626-629

12. Bischoff, HA, Stähelin HB, Urscheler N et al (1999) Muscle strength in the elderly: its relation to vitamin D metabolites. Arch Phys Med Rehabil 80(1):54-58

13. Dhesi JK, Bearne LM, Monitz C, Hurley MV, Jackson SHD, Swift CG, Allain TJ (2002) Neuromuscular and psychomotor function in elderly subjects who fall and the relationship with vitamin D status. J Bone Miner Res 17:891-897

14. Dukas L, Schacht E, Bischoff HA (2003) Better functional mobility in community dwelling elderly is related to D-hormone and a minimal calcium intake of more than $512 \mathrm{mg} /$ day. Osteoporos Int 14(7):S34

15. Bischoff HA, Stähelin HB, Dick W et al (2003) Fall prevention by vitamin $\mathrm{D}$ and calcium supplementation: a randomized controlled trial. J Bone Miner Res 18(2):343-351

16. Gallagher JC, Fowler SE, Detter JR et al (2001) Combination treatment with estrogen and calcitriol in the prevention of age-related bone loss. J Clin Endocrinol Metab 86(8):36183628

17. Dukas L, Bischoff HA, Lindpaintner LS, Schacht E, BirknerBinder D, Thalmann B, Stähelin HB (2004) Alfacalcidol reduces the number of fallers in a community-dwelling elderly population with a minimum calcium intake of $500 \mathrm{mg}$ daily. J Am Ger Soc 52:230-236

18. Bonjour JP, Rizzoli R, Caverzasio J (1992) Phosphate homeostasis, 1,25-dihydroxyvitamin- $\mathrm{D}_{3}$, and hyperparathyroidism in early chronic failure. Trends Endocrinol Metab 3:301-305

19. Reichel H, Deibert B, Schmidt-Gayk H, Ritz E (1991)Calcium metabolism in early chronic renal failure: implications for the pathogenesis of hyperparathyroidism. Nephrol Dila Transplant 6(3):162-169

20. Trombetti A, Stoermann-Chopard C, Ferrari S, Saudan P, Chevalley T, Binet I, Uebelhart B, Rizzoli R, Martin PY (2003) Prävention von Knochenkomplikationen bei Patienten mit chronischer Niereninsuffizienz (1.Teil). Swiss Med Forum 11:260-266

21. Francis RM, Peacock M, Barkworth SA (1984) Renal impairment and its effects on calcium metabolism in elderly women. Age Ageing 13:14-20

22. Nguyen TV, Eisman JA, Kelly PJ, Sambrook PN (1986) Risk factors for osteoporotic fractures in elderly men. Am J Epidemiol 144:255-263

23. Martinez I, Saracho R, Montenegro J, Liach F (1997) The importance of dietary calcium and phosphorous in the secondary hyperparathyroidism of patients with early renal failure. Am J Kidney Dis 29:496-502

24. Poor G, Atkinson EJ, O'Fallon WM et al (1995) Predictors of hip fracture in elderly men. J Bone Miner Res 10:1900-1907

25. US Kidney Foundation (2003) K/DOQI practice guidelines for bone metabolism and disease in chronic kidney disease. Am J Kidney Dis 42:S7-S28 
26. Klawansky S, Komaroff E, Cavanaugh PF, Mitchell DY, Gordon MJ, Connelly JE, Ross SD (2003) The relationship between age, renal function and bone mineral density in the US population. Osteoporos Int 14:570-576

27. Epstein S, Bryce G, Hinman JW et al (1986). The influence of age on bone mineral regulating hormones. Bone 7:421-425

28. Tsai KS, Heath H III, Kumar R et al (1984) Impaired vitamin D metabolism with aging in women: possible role in pathogenesis of senile osteoporosis. J Clin Invest 73:1668-1672

29. Dukas L, Bischoff HA, Schacht E et al (2002) Normal $25(\mathrm{OH})$ vitamin $\mathrm{D}$ serum levels do not exclude D-hormone deficiency in community-dwelling elderly. Osteoporos Int 13(1):S35

30. Slovik DM, Adams JS, Neer RM et al (1981) Deficient production of 1,25-dihydroxyvitamin $\mathrm{D}$ in elderly osteoporotic patients. N Engl J Med 305:372-374

31. Cockroft DW, Gault MH (1975)Prediction of creatinine clearance from serum creatinine. Nephron 16(1):31-41

32. Winer B (1971) Statistical principles in experimental design, 2nd edn. McGraw-Hill, New York, pp 171-514

33. Pagano M, Gauvreau K (1993) Probability. In: Principles of biostatistics, 1st edn. DuxburyPress, Belmont, CA, pp 115-145

34. Stern G, Thonchin M, Smith R (1973) Muscular weakness in metabolic bone disease. Neurology 20:480-483

35. Sorenson OH, Lund BI, Saltin B et al (1979) Myopathy in bone loss of ageing: improvement by treatment with $1 \alpha$-hydroxycholecalciferol and calcium. Clin Sci 56:157-161

36. Patten MP, Mallette LE, Prince A, Aurbach GD, Bilezikian JP, Kin-Engel W (1974) Neuromuscular disease in primary hyperparathyroidism. Ann Intern Med 80:182-193

37. Garber AJ (1983) Effect of parathyroid hormone on skeletal muscle protein and amino acid metabolism in the rat. $\mathbf{J}$ Clin Invest 71:1806

38. Baczynski R. Massry SG, Magott M, el Belbessi S, Kohan R, Brautbar N (1985) Effect of parathyroid hormone on energy metabolism of skeletal muscle. Kidney Int 38:722-727

39. Boland R (1986) Role of vitamin D in skeletal muscle function. Endocr Rev 784:434-448

40. Müller K, Haahr PM, Diamant M, Rieneck, Kharazmi A, Bendtzen K (1992) 1,25-dihydroxyvitamin $\mathrm{D}_{3}$ inhibits cytokine production by human blood monocytes at the post transcriptional level. Cytokine 4(6):506-512

41. Zofkovà I, Kancheva RL, Bendlovà B (1997) Effect of $1,25(\mathrm{OH})_{2}$ vitamin $\mathrm{D}_{3}$ on circulating insulin-like growth factorI and $\beta_{2}$ microglobulin in patients with osteoporosis. Calcif Tissue 60:236-239

42. Cappola AR, Xue Q L, Ferrucci L, Guralnik JM, Volpato S, Fried LP (2003) Insulin-like growth factor I and Interleukin-6 contribute synergistically to disability and mortality in older women. J Clin Endocrinol Metab 88:2019-2025

43. Stein MS, Wark JD, Scherer SC, Walton SL, Chick P, Di Carlantonio M, Zajac JD, Flicker L (1999) Falls related to vitamin $\mathrm{D}$ and parathyroid hormone in Australian nursing home and hostel. J Am Ger Soc 47:1195-1201

44. Bischoff HA, Borchers M, Gudat F et al (2001) In situ detection of 1,25-dihydroxyvitamin $\mathrm{D}$ receptor in human skeletal muscle tissue. Histochem 33:19-24

45. Haddad JG, Walgate J, Min C et al (1976) Vitamin D metabolite binding proteins in human tissue. Biochem Biophys Acta 444:9251-9255

46. Verhaar HJJ, Samson MM, Jansen PAF et al (2000) Muscle strength, functional mobility and vitamin D in older women. Aging Clin Exp Res 12:455-460

47. Dhesi JK, Bearne SHD, Jackson SHD et al (2003) Vitamin D supplement improves functional performance and postural sway in elderly people who fall. Age Ageing 31[Suppl 2]:26

48. Koike T, Okawa T, Wada M, Kita T, Takaoka K (2003) Effects of a long-term alfacalcidol or calcitonin administration on body sway in Japanese elderly women. J Bone Miner Res 18(S2):S168

49. Shaw FE, Bond J, Richardson DA, Dawson P, Steen IN, McKeith IG, Kenny RA (2003) Multifactorial intervention after a fall in older people with cognitive impairment and dementia presenting to the accident and emergency department: randomised controlled trial. BMJ 326(7380):73

50. Woolf AD, Akesson K (2003) Preventing fractures in the elderly. BMJ 327(7406):89-95 